\title{
The Formation of Isocitratase by the Athiorhodaceae
}

\author{
By H. L. KORNBERG AND JUNE LASCELLES \\ Medical Research Council Unit for Cell Metabolism and Microbiology \\ Unit, Department of Biochemistry, University of Oxford
}

(Received 30 May 1960)

\begin{abstract}
SUMMARY
Isocitratase, which cleaves isocitrate to glyoxylate and succinate and is a key enzyme in the glyoxylate cycle, is formed by Rhodopseudomonas palustris and $R$. capsulatus when grown on acetate or butyrate either anaerobically in light or aerobically in the dark. Only traces of the enzyme are present in organisms grown on succinate or malate. In contrast, isocitratase is detectable in traces only in $\boldsymbol{R}$. spheroides and Rhodospirillum rubrum grown on acetate, butyrate or other substrates. This suggests that the glyoxylate cycle cannot account for net synthesis of cell constituents from acetate or acetate precursors in these latter two organisms.
\end{abstract}

\section{INTRODUCTION}

Many photosynthetic bacteria of the Athiorhodaceae family can grow on bicarbonate + acetate, butyrate or other fatty acids as carbon source (van Niel, 1944), and the catabolism of these organic substrates has been shown by various techniques to proceed via the tricarboxylic acid cycle (Glover, Kamen \& van Genderen, 1952; Eisenberg, 1953; Elsden \& Ormerod, 1956). The synthesis of cellular materials during growth demands the occurrence of reactions which effect the net formation of intermediates of the tricarboxylic acid cycle from the growth substrates. In many micro-organisms (reviewed by Kornberg, 1959) this is accomplished via the glyoxylate cycle (Kornberg \& Krebs, 1957; Kornberg \& Madsen, 1957; 1958), a key enzyme of which, isocitratase (Smith \& Gunsalus, 1954, 1955, 1957; Olson, 1954, 1959; Saz \& Hillary, 1956), is formed only when such micro-organisms grow on acetate or precursors of acetate (Smith \& Gunsalus, 1955; Callely, Dagley \& Hodgson, 1958; Kornberg, Gotto \& Lund, 1958; Kornberg \& Lund, 1959). The main purpose of this paper is to show that, of the Athiorhodaceae examined, Rhodopseudomonas palustris and $\boldsymbol{R}$. capsulatus form isocitratase adaptively when grown on acetate or on precursors of acetate, both anaerobically in light and aerobically in the dark. Since the organisms also contain malate synthetase (Wong \& Ajl, 1956) the glyoxylate cycle can operate in these organisms under these conditions. However, although $R$. spheroides and Rhodospirillum rubrum also contain malate synthetase, they are virtually devoid of isocitratase under all conditions tested, and must therefore differ in the pathways of biosynthesis from acetate from all other micro-organisms examined. 


\section{METHODS}

Organisms. The following strains of Athiorhodaceae were used: Rhodopseudomonas spheroides NCIB no. 8253, Rhodospirillum rubrum NCIB no. 8255, Rhodopseudomonas capsulatus and $R$.palustris no.2.3.11 and no.2.1.7, respectively, from the collection of Professor C. B. van Niel. Stock cultures of all organisms were maintained as described previously (Lascelles, 1956).

Media. The basal medium used contained (mg./l.): $\mathrm{KH}_{2} \mathrm{PO}_{4}$ and $\mathrm{K}_{2} \mathrm{HPO}_{4}$, 500 each; $\left(\mathrm{NH}_{4}\right)_{2} \mathrm{HPO}_{4}, 800 ; \mathrm{MgSO}_{4} .7 \mathrm{H}_{2} \mathrm{O}, 200 ; \mathrm{CaCl}_{2}, 40 ; \mathrm{MnSO}_{4} .4 \mathrm{H}_{2} \mathrm{O}, 4$; ferric citrate, 3; nicotinic acid and thiamine hydrochloride, 1 each; biotin, 0.01. For growth of Rhodopseudomonas palustris, $p$-aminobenzoic acid $(0 \cdot 15 \mu \mathrm{g}$./l.) was also added. The basal medium was supplemented as required with DL-malate (20 $\mathrm{mM})$, succinate $(10 \mathrm{~mm})$, acetate $(20 \mathrm{~mm})$ or butyrate $(10 \mathrm{~mm})$, all added as the sodium salts. Sodium bicarbonate $(6 \mathrm{~mm})$ was included in all media containing acetate and butyrate as carbon source; the stock solution $(0 \cdot 6 \mathrm{M})$ was sterilized separately by autoclaving and added aseptically after equilibrating with $\mathrm{CO}_{2}$. Media were sterilized by autoclaving at $121^{\circ}$ for $10 \mathrm{~min}$.

Growth tests. These were carried out in $10 \mathrm{ml}$. volumes of media in tubes of $15 \mathrm{~mm}$. diameter. Inoculation was with $0 \cdot 1 \mathrm{ml}$. of a $1 / 100$ dilution (about $4 \times 10^{6}$ organisms) of a $24 \mathrm{hr}$. culture grown anaerobically in light on a medium containing malate, glutamate and yeast extract (Lascelles, 1956). Anaerobiosis was achieved by addition of a few crystals of pyrogallol and a drop of saturated $\mathrm{K}_{2} \mathrm{CO}_{3}$ to the cotton plug which was forced below the rim of the tubes; they were then sealed with rubber bungs. Tubes were incubated at $32^{\circ}$ to $34^{\circ}$ at $20 \mathrm{~cm}$. distance from a bank of $60 \mathrm{~W}$. tungsten lamps.

Growth and preparation of organisms for cell-free extracts. Cultures were grown anaerobically in light in $8 \mathrm{oz}$. medical flat bottles containing $200 \mathrm{ml}$. of medium and stoppered with a rubber bung. The inoculum and details of incubation were described by Lascelles (1956). Aerobic cultures of Rhodopseudomonas spheroides were grown in $500 \mathrm{ml}$. medium in $2 \mathrm{l}$. Erlenmeyer flasks; the other organisms were grown in $900 \mathrm{ml}$. medium in flasks of the same size. Inoculation was with 2-5 ml. of $24 \mathrm{hr}$. culture developed anaerobically in the light in a medium containing malate, glutamate and yeast extract (Lascelles, 1956). Incubation was at $32^{\circ}$ in a gyrorotary shaker (New Brunswick Instrument Co., New Jersey, U.S.A.) at 180 oscillations/min.

Cultures were harvested during or towards the end of the logarithmic phase of growth, the incubation time varying between 18 and $24 \mathrm{hr}$. for photosynthetic cultures and from 24 to $48 \mathrm{hr}$. for aerobic ones. Organisms were harvested by centrifugation, washed with one-half the original culture volume of 0.02 M-potassium phosphate buffer $(\mathrm{pH} 7 \cdot 0$ ), and finally suspended in the same buffer $(40 \mathrm{mM})$ to give a concentration of organisms equivalent to 1 to $10 \mathrm{mg}$. dry wt. $/ \mathrm{ml}$.

Preparation of extracts. These were prepared by ultrasonic vibration as described before (Lascelles, 1959). The disrupted preparations were spun at $0^{\circ}$ for $10 \mathrm{~min}$. at $25,000 \mathrm{~g}$ and the supernatant fluid used in the enzyme assays.

Assay of enzymes. Isocitratase and malate synthetase were measured spectrophotometrically by the procedure of Dixon \& Kornberg (1959). The activity of 
isocitratase is expressed as the specific activity ( $\mu$ mole glyoxylate formed in the standard assay/hr./mg. protein).

Estimation of protein and bacteriochlorophyll. These were determined as described previously (Lascelles, 1959).

Measurement of growth. This was determined by turbidity measurements with an EEL photoelectric colorimeter (Evans Electroselenium Ltd., Halstead, Essex, England) with filter no. 608. Results are expressed as mg. dry wt. organism/ml. culture and were calculated from calibration curves prepared with suspensions of each organism grown anaerobically in light or aerobically in the dark.

\section{RESULTS}

Effect of carbon source on growth and bacteriochlorophyll formation

All the organisms grew anaerobically in light on acetate, butyrate, succinate or malate (Table 1). Bicarbonate was necessary for consistent growth from small inocula on acetate or butyrate but did not affect growth on the dicarboxylic acids. Except for Rhodopseudomonas spheroides the carbon source did not greatly influence. the level of bacteriochlorophyll in the organisms. In $R$. spheroides considerable variation was found, the pigment concentration in organisms grown on acetate being only one-tenth of that in those grown on malate (Table 1). The same substrates also supported aerobic growth (in the dark) of all the organisms.

Table 1. Growth and bacteriochlorophyll formation on various carbon sources by Rhodospirillum rubrum, Rhodopseudomonas spheroides, R. capsulatus and R. palustris

Cultures were incubated anaerobically in light for $72 \mathrm{hr}$. in $10 \mathrm{ml}$. volumes as described in the Methods. The concentrations of organic acids were as follows: succinate and butyrate, $10 \mathrm{~mm}$, acetate; DL-malate, $20 \mathrm{~mm}$. In addition, $\mathrm{NaHCO}_{3}$ (to $6 \mathrm{~mm}$ ) was added to all tubes after autoclaving. $p$-Aminobenzoic acid (to $1 \mu \mathrm{M}$ ) was included in the basal medium for Rhodopseudomonas palustris.

\begin{tabular}{|c|c|c|}
\hline Organism & Carbon source & $\begin{array}{c}\text { Bacterio- } \\
\text { chlorophyll } \\
\text { Growth } \\
(\mu \mathrm{m} \text {-mole } / \mathrm{mg} .\end{array}$ \\
\hline Rhodospirillum rubrum & $\begin{array}{l}\text { Succinate } \\
\text { Malate } \\
\text { Acetate } \\
\text { Butyrate }\end{array}$ & $\begin{array}{l}0 \cdot 68 \\
1 \cdot 21 \\
0 \cdot 67 \\
0 \cdot 12\end{array}$ \\
\hline Rhodopseudomonas spheroides & $\begin{array}{l}\text { Succinate } \\
\text { Malate } \\
\text { Acetate } \\
\text { Butyrate }\end{array}$ & $\begin{array}{l}0 \cdot 72 \\
1 \cdot 23 \\
0 \cdot 66 \\
0 \cdot 48\end{array}$ \\
\hline R. capsulatus & $\begin{array}{l}\text { Succinate } \\
\text { Malate } \\
\text { Acetate } \\
\text { Butyrate }\end{array}$ & $\begin{array}{l}0 \cdot 78 \\
0 \cdot 63 \\
0 \cdot 63 \\
0 \cdot 98\end{array}$ \\
\hline R. palustris & $\begin{array}{l}\text { Succinate } \\
\text { Malate } \\
\text { Acetate } \\
\text { Butyrate }\end{array}$ & $\begin{array}{l}0 \cdot 78 \\
0 \cdot 98 \\
0 \cdot 86 \\
1 \cdot 07\end{array}$ \\
\hline
\end{tabular}




\section{Isocitratase activity in extracts}

Extracts prepared from Rhodopseudomonas spheroides grown on acetate or butyrate either anaerobically in light or aerobically in the dark showed only traces of isocitratase. This activity was quite insufficient to contribute significantly to the ability of the organism to utilize these substrates for growth and was no higher than that found in malate-grown organisms. Extracts from organisms which had been successively transferred three times through acetate or butyrate medium were also inactive. Extracts of Rhodospirillum rubrum also had negligible isocitratase activity (Table 2).

Table 2. Isocitratase activity in extracts of Athiorhodaceae

\begin{tabular}{|c|c|c|c|}
\hline & & \multicolumn{2}{|c|}{$\begin{array}{l}\text { Isocitratase in } \\
\text { culture grown }\end{array}$} \\
\hline Organism & Growth substrate & $\begin{array}{l}\text { Anaerobic }+ \text { light } \\
(\mu \text { mole glyoxylate } / \mathrm{hr} .\end{array}$ & $\begin{array}{l}\text { Aerobic } \\
\text { /mg. protein) }\end{array}$ \\
\hline Rhodopseudomonas capsulatus & $\begin{array}{l}\text { Acetate } \\
\text { Butyrate } \\
\text { Succinate }\end{array}$ & $\begin{array}{l}1 \cdot 90 \\
1 \cdot 58 \\
0 \cdot 03\end{array}$ & $\begin{array}{l}1 \cdot 37 \\
2 \cdot 11 \\
0 \cdot 04\end{array}$ \\
\hline R. palustris & $\begin{array}{l}\text { Acetate } \\
\text { Butyrate } \\
\text { Malate }\end{array}$ & $\begin{array}{l}5 \cdot 4 \\
3 \cdot 4 \\
0 \cdot 07\end{array}$ & $\begin{array}{r}5 \cdot 6 \\
2 \cdot 4 \\
-\end{array}$ \\
\hline R. spheroides & $\begin{array}{l}\text { Acetate } \\
\text { Butyrate } \\
\text { Malate }\end{array}$ & $\begin{array}{l}0 \cdot 01 \\
0 \cdot 06 \\
0 \cdot 04\end{array}$ & $\begin{array}{l}0.01 \\
0.04 \\
0.03\end{array}$ \\
\hline Rhodospirillum rubrum & $\begin{array}{l}\text { Acetate } \\
\text { Malate }\end{array}$ & $\begin{array}{l}0.07 \\
0.05\end{array}$ & $\begin{array}{l}0.08 \\
0 \cdot 04\end{array}$ \\
\hline
\end{tabular}

Isocitratase activity was found in Rhodopseudomonas capsulatus and $\boldsymbol{R}$. palustris when grown on acetate and butyrate (Table 2). The specific activity of the isocitratase did not differ significantly in organisms grown anaerobically in light or aerobically in the dark (Table 2). Under both conditions and with both organisms it varied with the physiological age of the organisms at harvesting, reaching a maximum during the logarithmic phase of growth and then declining (Fig. 1).

As found in other organisms (see review, Kornberg, 1959) isocitratase in Rhodopseudomonas capsulatus and $\boldsymbol{R}$. palustris was adaptive, being formed only in organisms grown on acetate or butyrate (Table 2). In $R$. palustris addition of succinate to a culture growing on butyrate delayed development of isocitratase; synthesis of this enzyme was resumed after a period during which the added succinate was presumably utilized (Fig. 2). Suppression of isocitratase by succinate has been observed with other organisms (Kornberg et al. 1958; Kornberg, Collins \& Bigley, 1960).

Malate synthetase. Activity of this enzyme was found in all extracts of all organisms tested under all conditions of growth. Malate synthetase appears to be constitutive in Athiorhodaceae as it is in Pseudomonas spp. (Kornberg \& Lund, 1959). 

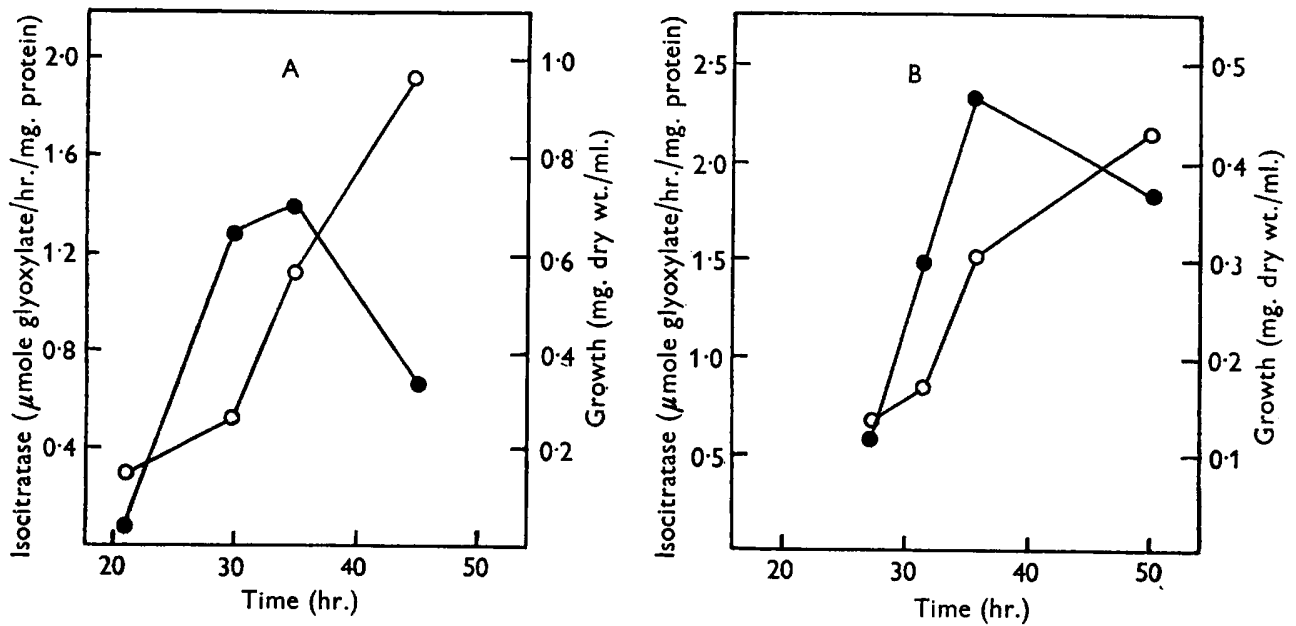

Fig. 1. Isocitratase activity of Rhodospeudomonas palustris at various stages of growth. Cultures were grown: anaerobically in light (A); aerobically in the dark (B) on butyrate medium. Samples were removed at intervals for determination of isocitratase activity $(-\odot-)$ and dry wt. (-O-).

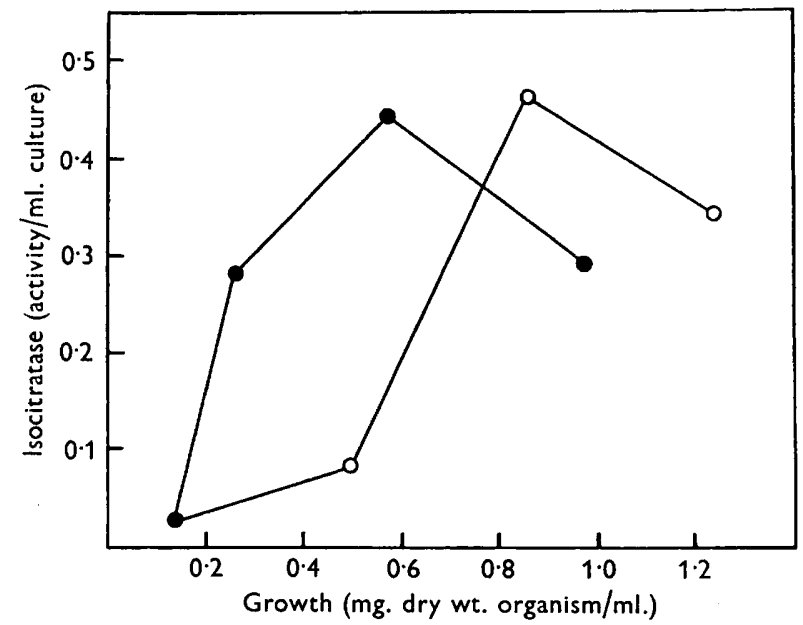

Fig. 2. Effect of succinate on the development of isocitratase in cultures of Rhodopseudomonas palustris. A culture growing anaerobically in light in butyrate medium was divided at the beginning of the exponential phase. Succinate (to $5 \mathrm{~mm}$ ) was added to one part and isocitratase activity determined at intervals thereafter (-O - ) . No addition was made to the other portion (- - ). Total isocitratase activity is expressed as the product of the specific activity and the suspension density and is plotted against the increase in culture density.

\section{DISCUSSION}

The tricarboxylic acid cycle, which has been shown to operate in members of the Athiorhodaceae, is sufficient as a means of providing both energy and the carbon skeletons of cell constituents when succinate or malate is the sole carbon source; but this cycle alone cannot account for growth on acetate or butyrate. In many types of micro-organisms the required synthesis of intermediates of the tricarboxylic acid cycle is effected via the glyoxylate cycle (see Kornberg, 1959). The ability to 
form isocitratase is a prerequisite for the operation of the glyoxylate cycle. It is therefore of some interest that isocitratase was not found in significant amounts in either Rhodospirillum rubrum or in Rhodopseudomonas spheroides when grown on acetate or butyrate, though it was present in $R$. capsulatus and $R$. palustris grown under the same conditions. The isocitratase-negative organisms did not appear to be at any obvious disadvantage to the isocitratase-positive organisms with respect to growth rate on these substrates, though the amount of bacteriochlorophyll formed in the light by $R$. spheroides on acetate or butyrate was markedly less than that formed by malate-grown cultures. Since Rhodospirillum rubrum and Rhodopseudomonas spheroides cannot use the glyoxylate cycle they must have other means for obtaining net synthesis of tricarboxylic acid cycle intermediates from acetate. The fact that added bicarbonate is necessary for growth of photosynthetic bacteria on fatty acids (van Niel, 1944) may be significant although, since only negligibly small amounts of isotope from added $\mathrm{NaH}^{14} \mathrm{CO}_{3}$ are incorporated by $\boldsymbol{R}$. spheroides aerobically metabolizing acetate, $\mathrm{CO}_{2}$ is unlikely to act directly as a main precursor of cellular materials under these conditions (Kornberg, to be published). Moreover, the operation of a reductive pentose cycle (Bassham \& Calvin, 1957), which could provide a net synthesis of tricarboxylic acid cycle intermediates, cannot account for aerobic growth of the isocitratase-negative organisms on acetate, since ribulose 1:5-diphosphate carboxylase is formed only by cultures growing anaerobically in light (Lascelles, 1960).

The role of the glyoxylate cycle in the isocitratase-positive organisms (Rhodopseudomonas palustris, $R$. capsulatus) cannot be quantitatively assessed from the present information. The enzyme was found only in organisms grown on acetate or butyrate and its formation was suppressed by succinate. Such behaviour is typical of organisms known to use the glyoxylate cycle. On the other hand isocitratase was formed by cultures growing anaerobically in light, where the cycle would not be required for net synthesis of tricarboxylic acid cycle intermediates, since these could be formed via the reductive pentose cycle. It is thus possible that, under these conditions, both biosynthetic routes operate simultaneously.

We are grateful to Professor Sir Hans A. Krebs, F.R.S. and Professor D. D. Woods, F.R.S. for their interest and encouragement. This work was supported by a grant to the Department from the Rockefeller Foundation. One of us (H.L.K.) received additional support from the Office of Scientific Research of the Air Research and Development Command, U.S. Air Force, through its European office, under contract no. AF 61(052)-180. One of us (J.L.) is a member of the External Scientific Staff of the Medical Research Council.

\section{REFERENCES}

Bassham, J. A. \& Calvin, M. (1957). The Path of Carbon in Photosynthesis. Englewood Cliffs, N.J. : Prentice-Hall, Inc.

Callely, A. G., Dagley, S. \& Hodgson, B. (1958). Oxidation of fatty acids by cell-free extracts of a vibrio. Biochem. J. 69, 173.

Dixon, G. H. \& Kornberg, H. L. (1959). Assay methods for key enzymes of the glyoxylate cycle. Biochem. J. 72, 3 P.

Eisenberg, M. A. (1953). The tricarboxylic acid cycle in Rhodospirillum rubrum. J. biol. Chem. 203, 815. 
Elsden, S. R. \& Ormerod, J. B. (1956). The effect of mono-fluoroacetate on the metabolism of Rhodospirillum rubrum. Biochem. J. 63, 691.

Grover, J., Kamen, M. D. \& van Genderen, H. (1952). Studies on the metabolism of photosynthetic bacteria. XII. Comparative light and dark metabolism of acetate and carbohydrate by Rhodospirillum rubrum. Arch. Biochem. Biophys. 35, 384.

Kornberg, H. L. (1959). Aspects of terminal respiration in micro-organisms. Annu. Rev. Microbiol. 13, 49.

Korngerg, H. L. \& KreBs, H. A. (1957). Synthesis of cell constituents from $\mathrm{C}_{2}$ units by a modified tricarboxylic acid cycle. Nature, Lond. 179, 988.

Kornberg, H. L. \& LUND, P. (1959). Influence of growth substrates on levels of glyoxylate cycle enzymes in Pseudomonas ovalis Chester. Biochem. J. 72, 33 P.

Kornberg, H. L. \& MADSEN, N. B. (1957). Synthesis of $\mathrm{C}_{4}$-dicarboxylic acids from acetate by a 'glyoxylate bypass' of the tricarboxylic acid cycle. Biochim. biophys. Acta, 24, 651 .

Kornberg, H. L. \& Madsen, N. B. (1958). The metabolism of $\mathrm{C}_{2}$ compounds in microorganisms. 3. Synthesis of malate from acetate via the glyoxylate cycle. Biochem. $J$. 68,549 .

Konnberg, H. L., Collins, J. F. \& (In PART) Bigley, D. (1960). The influence of growth substrates on metabolic pathways in Micrococcus denitrificans. Biochim. biophys. Acta, 39, 9.

KornBerg, H. L., Gotro, A. M. \& Lund, P. (1958). Effect of growth substrates on isocitratase formation by Pseudomonas ovalis Chester. Nature, Lond. 182, 1430.

LASCELles, J. (1956). The synthesis of porphyrins and bacteriochlorophyll by cell suspensions of Rhodopseudomonas spheroides. Biochem. J. 62, 78.

Lascelles, J. (1959). Adaptation to form bacteriochlorophyll in Rhodopseudomonas spheroides; changes in activity of enzymes concerned in pyrrole synthesis. Biochem. $J$. $72,508$.

LASCELLES, J. (1960). The formation of ribulose 1:5-diphosphate carboxylase by growing cultures of Athiorhodaceae. J. gen. Microbiol. 23, 499.

NIEL, C. B. vaN (1944). The culture, general physiology, morphology and classification of the non-sulfur purple and brown bacteria. Bact. Rev. 8,1 .

Orson, J. A. (1954). The d-isocitric lyase system: the formation of glyoxylic and succinic acids from d-isocitric acid. Nature, Lond. 174, 695.

Olson, J. A. (1959). The purification and properties of yeast isocitric lyase. J. biol. Chem. 234, 5.

Saz, H. J. \& Hillary, E. P. (1956). The formation of glyoxylate and succinate from tricarboxylic acids by Pseudomonas aeruginosa. Biochem. J. 62, 563.

Smith, R. A. \& Gunsalus, I. C. (1954). Isocitratase: a new tricarboxylic acid cleavage system. J. Amer. chem. Soc. 76, 5002.

Smith, R. A. \& Gunsalus, I. C. (1955). Distribution and formation of isocitritase. Nature, Lond. 175, 774 .

Smith, R. A. \& Gunsalus, I. C. (1957). Isocitritase: enzyme properties and reaction equilibrium. J. biol. Chem. 229, 305.

Wong, D. T. O. \& AJL, S. J. (1956). Conversion of acetate and glyoxylate to malate. J. Amer. chem. Soc. 78, 3230. 